\title{
Contributions of Gadamer to the Teachers Education in the Perspective of Full/Inclusive Education
}

\author{
Marlene Rozek1, Claus Dieter Stobäus ${ }^{2}$ \\ ${ }^{1}$ Postgraduate Programs in Education, Pontifical Catholic University of Rio Grande do Sul-PUCRS, \\ Porto Alegre, Brazil \\ ${ }^{2}$ Postgraduate Programs in Education and in Biomedical Gerontology, Pontifical Catholic University of Rio \\ Grande do Sul-PUCRS, Porto Alegre, Brazil \\ Email: stobaus@pucrs.br
}

Received 30 June 2016; accepted 23 August 2016; published 26 August 2016

Copyright (C) 2016 by authors and Scientific Research Publishing Inc.

This work is licensed under the Creative Commons Attribution International License (CC BY). http://creativecommons.org/licenses/by/4.0/

c) (i) Open Access

\section{Abstract}

This article proposes to analyze the contributions of the philosophical hermeneutics of HansGeorg Gadamer for teachers' education in the perspective of Full/Inclusive Education. It was conducted from discussions among the authors, based on Rosek Doctoral Thesis, with our experiences in the field of Full/Inclusive Education. In the educational context, it is necessary to understand the production of meanings about becoming and being a teacher and the act of educating, for teacher education can be also considered as a hermeneutic relationship, just as a way of productive relationships. The education of teachers, a practice that understands and interprets, reveals and makes sense, is contributing to the expansion of the horizon of understanding teacher relationships with their students in the school inclusion processes. The hermeneutic perspective in understanding the teaching shows it is relevant because it allows the construction of interpretive horizons about himself and the others, which allows broader understanding of human interpersonal relationships and own educational act. It is also important to remember and reflect on the influences of other topics, such as knowledge and skills of teachers who work in Special/Inclusive Education, including the concepts they use and how they see that it operates, as well as affectivity and healthier interpersonal relationships.

\section{Keywords}

Teacher Education, Philosophical Hermeneutics, Full Inclusion/Inclusive Education, Gadamer 


\section{Introduction}

This study aims to analyze the contributions of philosophical hermeneutics of Gadamer $(2002,2007)$ to the field of teacher education. The meeting with the references of Philosophical Hermeneutics provides a glimpse of a comprehensive horizon about teacher education and its development in relation to the other.

It is understood that teacher training should include the development of production experience of themselves as improvers' events of the exercise amounts as teaching and own pedagogical relationship are ethical endeavors, manifested by the ways in which teachers relate with the knowledge and others.

It is understood that the relationship between teachers and students and the pedagogical own show, more or less explicitly, the model of rationality. Similarly, the personal and professional/academic teacher is based on a model of rationality that sustains and legitimizes. Therefore, it is important to understand pathways, processes, routes, and senses movement of the forming process; it means thinking about the process of formation of the subject teacher and the production itself.

In this perspective, the hermeneutic path is the possibility of a "self clarification test", because it is a process of interpreting the experience as an act of construction of meaning about themselves. This study points to the importance of understanding the discursive horizons that constitute being a teacher in his personal and academic journey and professional training. So I think the subject-teacher training process requires thinking the process of production itself.

Therefore, possible to think philosophically becomes teacher training, seeking to give a look/singular meaning to the concept of training, because it is considered essential to understand how the subject teacher is building and configuring its existence as a teacher. This understanding of teaching as a relationship experience can allow the search of savoir-vivre with themselves and with others.

The idea of rationality given by Gadamer (Rozek, 2013) is more as only having subjectivity and rationality, essential to understand the education process, with a subject in construction and a world of sense that he built, in which this subject is linked to that he/she constructs in this the world. Not only in the Kantian sense, must we be open to each other to build our own sense, a critique of the prevailing rationality model.

Our text was constructed from the discussions of our ideas as group. Rozek's research was approved on Ethical Committee at Universidade Federal do Rio Grande do Sul-UFRGS.

\section{Philosophical Hermeneutics of Hans-Georg Gadamer}

In the context of Modernity hermeneutics resurfaces to show that there are other ways of knowing reality. His new way of understanding lies in the change of contemporary thought that Rorty (1990) names as linguistic turn. This expression marks a cleavage point to the philosophical foundations of modern design and breaks with the philosophical traditions that have supported the scientific ideal of Western Modernity. Thus, it has been placed under suspicion the idea of truth as correspondence with reality. The truth is immersed in the dynamics of time and life, not existing as essence out of its historicity.

Hans-Georg Gadamer, 1900-2002 defines philosophy as a permanent reflection on what should be the setting of human life, builds a very conception of hermeneutics as a philosophy rooted in Greek thought, extracting it, especially the art the Socratic-platonic dialogue and the Aristotelian concept of phronesis, usually translated as prudence or practical wisdom.

In the words of Gadamer (2007: p. 31), hermeneutics:

[...] It is not a methodology of human sciences, but an attempt to understand what is truly the humanities in addition to their methodological self-consciousness, and that connects to the totality of our experience of the world.

Hermann (2007: p. 366), this Phronesis:

[...] Is a practical wisdom because it concerns the action involving the particular cases, so human actions can not be thought to the concepts of theoretical science. It is a knowledge that surrounds us, we are already involved.

The Philosophy it is an endless dialogue, in which comprehension is a way to exist and even more universal forms of existence. Understanding act becomes more fundamental and more comprehensive than the know and what the thinking, writing as a condition of possibility of other dimensions of existence. Understanding has, for the author, an original dimension, as it recognizes the essential behavior of man in his relationship to the world. One can say that Gadamer's hermeneutics is organized in a posture, a way of being that articulates the under- 
standing of truth and good, through the dialogical exercise.

We experience our own experiences while immersed in our historicity (Gadamer, 2002). The real experience is the experience of this same human historicity. Thus, it is possible to understand yourself and others as historical beings, whose identity and categories of knowing result of their belonging to a particular story.

Truth and Method, Gadamer's (2002) work, first published in 1960, is part of the complaint movements of the positivist methodological paradigm. Within a culture marked by the predominance of science and technology, the author seeks to break with the positivist barrier that prevents an appropriate relationship between philosophy and science. Criticizes and blames positivism for the inhuman aspects of contemporary society; confirms that there operated in response to the changes, the tendency for humanization is emphasized more and more.

In this perspective, hermeneutics is concerned with the ethical education of existence, with the recognition that the human being is a being in formation, always inhabited by otherness and the effect of the relationship.

Gadamer approaches the critique of instrumental reason and reason-dimensional developed by the Frankfurt School, in holding that the domain objectifying thought bears the seal of a rigid subjectivity, instrumentalized for the purpose of self-assertion. In this sense, it is proposed to think a human and social practice that is not limited to the mechanical application of the technique. Seeks to show that, in addition to the scientific method, there are other ways of knowing reality. The central issue is to understand the human experience, knowledge and make human, maximum issues decisive for the man and for the choice of good.

The hermeneutics that takes care of that truth does not submit to methodical rules of human sciences, reason is philosophical hermeneutics call and is understood as an art and not a mechanical procedure. Your task is to clarify the conditions under which comes the understanding, and not to develop a comprehensive procedure. Hermeneutics need to ask the way it happens, which involves raising the foreground the temporal distance and its significance for understanding.

The senses historically produced by language are conditions of the possibility of acting in the world, because there is no action possible in a vacuum of meaning, there is no experience that is not mediated by language. It is understood that all human action arises from certain understanding/interpretation of something that makes sense in a context/universe full of numerous sense keys, an existence made linguistically. Thus, by adopting an interpretative hermeneutic perspective in the educational field, the formation of the subject teacher will operate with a concept named as linguistic reality, possible several readings. This allows us to consider teacher training as a text, it is understood that it is within this repertoire of social meanings that training, as performance practice, will trigger emphases and build a comprehensive pathway complex field of teacher education. Thus, teacher training, a practice that understands and interprets, reveals and makes sense, is contributing to the expansion of the horizon of understanding teacher relationships with their students.

Another point to be cleared is the use of the term historicity, by Gadamer. As say Adams \& Junges (2010):

The question of historical consciousness, Gadamer second is the revolution higher importance of human knowledge has achieved since the modernity. It became a "privilege" and also a "Burden" of the contemporary human in his acting and knowing, as a condition to know about man and about the experience of know, justified in the historical horizon of belongingness of the present and past life.

Hermeneutics takes awareness of the impossibility of thinking a subject detached from its history. The knowledge revealed in the historicity and language and binds the subject to understand the historicity. For Gadamer (2007), the story is always understood in reference to this and understanding is not essentially a subjective activity, but an insert in the transmission process in that mediate the past and present.

\section{Reflections about Teachers Education}

Human life is configured as a dialogical process. For Gadamer (2002, 2007), priority of the relationship with the other, that this can also be right, determines the soul of hermeneutics. For him, a word that does not reach the other is dead. Dialogue is an experience that shows essentially the intersubjective dimension of life and ethical life.

We need words that refer us to dialogue, words that are not exhausted in absolutes, but seek provisional truths and constitute considering the vulnerability of the human condition in relation to others, that is, the constant need we have another to establish ourselves as historical subjects. Only we understand who the other is to understand the narrative that he or others do to us. Thus, the relationship between narrative, the comprehensive act and the self is narrow. 
In this context, the choice of profession can be considered a biographical event, happening in a socio-historical field of senses and meanings, which are given choices and identifications entered in the paths of teachers. Biography and professional contribute to the formation of a subject, which is always social and bears the marks of tradition and its inserts. Soon, biographies and professionalism are important spaces in the understanding of the subject teacher and the meanings that were built in relation to teaching.

In the educational field, it is understood that teacher training can be thought of as a hermeneutic relationship, therefore, a way production ratio. Built senses and meanings front of the living. Thus the text of our life as well as all text may be subject to multiple interpretations. Make sense of what happens to us is to translate the signs in its many forms.

Every human being needs to go through the history of mankind itself and culture to them constitute living and active part. It must take the meaning of life with the ability to articulate the inter word and action, his own biographical experience.

While subject learning, entered and made up of the learning, the human being can not unlink what makes the world what makes of himself, for his reflective capacity (Marques, 2003). And it is precisely in the articulation of these two instances-the self and the world-that is the ability of reflection, that is, the possession of his knowledge about yourself and about the world.

Relying on Gadamer's ideas, Marques (2003) states that the formation means to break with the immediate and natural; means to remain open to the other, the distinct otherness and the many possibilities, the distinct and general points of view, that cover other possible points of view. Training involves an extended space where everyone can move without constraints, has the ability to see everything with eyes always new, inquisitive and may have sensitivity and tact to perceive situations and requirements, which requires theoretical foundation of knowledge, built on tradition culture and construction of other (new) knowledge.

The formation, a critical and reflective perspective, should provide teachers with the means of an autonomous thinking. Being in training entails a personal investment, a free and creative work on the routes and the projects themselves, with a view to building an identity, which is also a professional identity (Nóvoa, 1995). This is built based on the meaning of the movement of teachers and in the sense that the professional gives to his work, defining what you want and what you do not want and what you can do as a teacher.

Veiga (2006), reflecting on teaching and its development training, identity and didactic innovation, says the training to be linked to the life history of the subject, is in permanent construction process of transformation; therefore, never be ready, complete. It is not built by the accumulation of courses, techniques, knowledge, but through a critical reflection on work practices and (re) construction of a permanent personal identity. Herein lies the importance of investing in the subject and to give a status to learn built by way of experience.

In general, the training of teachers has ignored the personal dimension of teacher Nóvoa (1995: p. 24), "not realizing that the logic of educational activity does not always coincide with the dynamics of their own training."

In this study, the concept of training is taken not only as a learning activity carried out in time and precise spaces, but also as a vital action of building itself. Form is supposed exchanges, experiences, interactions, learning, teaching, endless relations; a journey of life is a training course (Moita, 2002).

In this perspective, training has the experience, the new test, passes through research processes, directly articulated to educational practices. The challenge, for Nóvoa, is to design the school as an educational environment where work and form are not different activities.

For this author, the experience is something unique that cannot be repeated in the course of life, time and knowledge. Thus, each teacher, despite living the same event, live the experience of teaching in a unique and singular way.

The study of teacher training requires understanding the different movements that are constitutive of this process. Become a teacher, be teacher and is a production of itself that makes the dynamics of society and culture. Production of being a teacher cannot be an a priori definition; rather, it is a whole contingency constitution of the pedagogical, the subject in practice and practice. The training needs to recognize and value the personal as well as professional experience of the subject teacher. The construction and reconfiguration of subjectivities cannot be detached from the formation of the subject teacher. It is in this context of intense and complex relationships, the teacher constitutes, and the various experienced and lived moments become processes of such training.

The training of general teachers and pedagogy itself require the philosophical attitude as an intellectual tool. 
philosophical attitude is here understood as reflecting the question, dig the real surface to reach the bases that guide and justify the pedagogical action. Thus, it is understood that it is necessary to build the meaning of education through philosophical reflection.

We are immersed in a historical context that not only constituted the pedagogical practices, as well as own subjectivities teachers.

Human life can be experienced with various events; there are those who are experienced in a very personal way, given the passing of transferable form. There are also others that have a meaning, not only as individual subjects, but as human beings. Considering this perspective, it is understood that the training of teachers need a deep reflection on the culture and history as it introduces its concept of education and his speeches. Reference is made to education as an ethical practice interested in the formation of the subject in an educational ethical, which is based on the idea of responsibility toward the other.

Education, authentic training experience, constitutes an event of ethical within which is a human relationship, that is, a subject that transcends the other and against which it is committed to taking responsibility.

Arendt (2008), in The Human Condition, says that the modern age has lost its confidence in the wisdom of the senses and in appearances. The reality is manifested in their appearances, which means that the modern age has lost its trust in reality. The construction of reality is always symbolic order. Here, the symbolic is understood to this gesture that always refers to a direction that is not clearly visible in an immediate way. It is something that is a meaning that is not inherent.

Education, in the design of Arendt, have to refer to another figure, that is, it is necessary that the level of experience beyond the empathy phenomenon. This leads to understand education as an ethical enterprise in response to demand from the other. An ethical perspective prints an inclusive logic, logic that this agenda in recognition and appreciation of the other.

How to be interpretive, in search of meaning and understanding, the human being is a hermeneutic, a mediator, a being who needs to move into intermediate and textual spaces; he has to learn the art of deciphering meanings, the same art of hermeneutics.

Contemporary societies marked and orientates the dominance of instrumental reason in prevailing concepts and technical practices, fail to realize the fruits of human interactions. Gadamer (2007) associates this characteristic of the contemporary world-the inability for dialogue-technical and scientific development. This inability to form dialogue is an important impediment to the pedagogical action, because the whole educational process occurs in interactions with and between the subjects. The dialogue cannot exist between individuals who cannot take a listening attitude.

The "gadamerian" thinking helps us to realize the inability to dialogue beyond the walls of the school, that is, as an almost general trend of the contemporary world, involving people, institutions, groups and many other segments of society. It is in this context that the dialogue needs to be rescued as the lynchpin of human sciences and pedagogy itself.

The modern world has built features that enable knowledge by different means, however, we must have the insight that these means do not eliminate the need of interactions, as they bring with them the concepts of technical, like efficiency and competitiveness. In general, the field of education has become an area of resources and procedural techniques, away from a theoretical and reflective rationality, going to act based on common sense, impoverishing the educational process of their subjects. In the absence of reflection, the school institution closes for dialogue, either with the theories already systematized, either with their peers in the educational context (Rozek, 2010).

The human dialogue implies a subject relationship that share the word, with the possibility of listening, because without it, no effective dialogue; dialogue presupposes the existence of knowledge that are not absolute, making the subject perceives is inconclusive and recognizing that the other is able to possess different knowledge. The authentic dialogue presence in the educational process is crucial, as well as promote more fraternal bonds, leading to the understanding of the existential horizon of the other.

The dialogue, not a methodological procedure is organized in the very strength of education and teaching, to a constant confrontation with yourself, with your opinions and beliefs (Hermann, 2002: p. 95), while the dialogue leads to opening horizons, which "allows education to enforce the polysemy of discourse and create a mutual understanding of space between those involved".

Thus, in the educational field, there is need to recognize dialogue as a mediating element of practical and inclusive pedagogical relationships and humanizing. The result has been difficult to establish, in dialogical, a 
broader understanding possibility of the other.

The pedagogical action requires interaction focused on dialogical formation of the subjects that make up this process, as with the living dialogue, lies the ability to seek a meeting with the other, want to listen to it, and with it, understand it.

To characterize the living dialogue, Gadamer (2002) puts it in the context of the Greek distinction between techné and praxis. Whereas techné guided by a rationality that aims to manufacture a product whose human action lies outside itself, the practice is constituted by a rationality that requires an action that resides in the same action and not outside it, which it means the requirement of personal reflection and the very understanding of the subject of his actions, as well as assuming responsibility for the decisions.

In this sense, the pedagogical action can be understood as a living dialogue, a procedural move that builds its own internal dynamics, far from making a mechanical and meaningless, indifferent to the needs of the other. Thus, in the process of building knowledge, something you do understand to the extent that the person who seeks to understand to be able to hear the other, to establish a relationship of alterity in a meeting authentic dialogical, in which we are no longer the same because we become in this relationship.

Gadamer teaches us that knowledge is a construction of experience, structured hermeneutically, in which the truth is multiple, historically located and linked to the context in which knowledge gives. Knowledge is hermeneutically built from the phenomenon with which the knower comes into contact and not a simple representation or copy of the real, which requires a continuous interaction.

To believe that what we know does not reveal essences, but are human constructions, it is possible to develop an open and subjectivity in favor of accepting the other, with its particular way of being, of living and the satisfaction of being at his side. Thus, the other happens to be conceived as a source of wealth before unknown.

The daily school is primarily an organization of space-time of teaching, experience that can only be understood by the set of circumstances that makes it possible. So think teacher training as a relationship experience implies an attentive and sensitive listening to others and the pursuit of understanding of the multiple movements that make teaching an experience in Gadamerian sense considering that our world experience is fundamentally interpretive (Hermann, 2002).

We live in a world that can only exist if we create with each other. The acceptance of the other becomes the ontological condition so that we can exist as humans. So I believe it is a necessary condition that the subject teacher to develop an open subjectivity the differences and specificities of each other. In this way, the other is seen not as a threat but as a source of wealth, just to have a different truth of mine. Thus to realize in Gadamer's hermeneutics, otherness relationship where we are invited to rethink our attitude in relation to each other. It is understood that the opening is another key element in recognizing the need for a process of humanization (Rozek, 2010).

\section{Educational Process Interfaces in Special Education}

In one of our articles (Teixeira, Mosquera, \& Stobäus, 2015), we just point on the conceptions that teachers, an often also the (special) students and their parents have and manifest about Special education/Full Inclusion,

We need to understand that the production of meanings in the case of the education process(es) to become and be a teacher, to be better prepared to think and act when he/he is on field is(are) mostly related to three moments: knowledge, skills and attitudes (Mosquera \& Stobäus, 1984: p. 55). If the teacher is well in his/her knowledge, it means that their preparation was good or very good, in the academic field (and also in the personal if it is possible):

The teacher is a mediator when establishing dyadic relations, warm and deep with his students, and is a facilitator when you are inclined to help students overcome specific problems. The facilitator idea, at this moment, tells us that teachers would be more interested in helping more the "problematic students" that the "properly-successful students".

Other points to consider are the ideas of Ausubel (Mosquera \& Stobäus, 1984: p. 60), who "states that four factors are important for the understanding of a teacher: their cognitive skills, personality characteristics, teaching styles and school discipline".

According Ausubel, in the cognitive skills the aspects are: Understanding, Stability Consistency Clarity and precision of concepts: Integration between the behavioral aspects of the area, Awareness of the significant theoretical issues and the underlying philosophical assumptions, Understanding of the methodological and episte- 
mological aspects.

Here we can complement in direction of the skills of the teacher, including capacity of leadership, (healthy and positive) interpersonal relationships, resilience or entrepreneurship.

In the in personality characteristics we need Affection: Fairness: Justice: Patience: Good mood: Warm Understanding: Interest in the students: Friendliness.

The teaching styles would be give emphasis to expository and discussion elements. Give only expositive classes can be good, but having also discussions with the students can be very productive. Also, give only texts for group discussion, without creating moments with the teacher sharing opinions and expanding ideas can be unproductive.

And on school discipline: laissez-faire, authoritarian and democratic disciplinarian.

The third point is not mostly so objective. Is referred to the attitudes of the person (in these case of the teacher), i.e. when he give the classes, observe student, made (positive and carefully) interventions, give feedback. All of these preparations when we speak about teachers education are necessary, more or less, during their academic preparation, especially when they go to field, in practice.

Teachers must also understand the importance of a good/real self-image and self-esteem (Lettnin, Dohms, Mendes, Stobaus, Mosquera; \& Jesus, 2015).

Dohms, Lettnin, Mendes, Mosquera, \& Stobäus (2014: p. 1783), speaking about the necessary presence of affectivity in Education, emphasize that "affect is very important in the educational context and depends on individual training (self) so you can be used positively in this environment as a tool for learning, and for healthy interpersonal relationships (contextualization)”.

Mosquera, Stobäus, \& Huertas (2015), in the articulation between the narratives of the teachers (and of course the students and their family), pointed out that it is necessary know well how to speak to the other person, so that the issuer to make understand the receiver, clearly and more objective.

As says Rozek (2012: p. 137):

Certainly, the work on our own process of training and knowledge makes it possible to manage more sensitively the operating dynamics of the other. Reflect on our own biographical path points to the possibility of transforming our process and live the pursuit of diversity and respect for plurality in our teaching daily, in the way we relate to our students, we think our classes, we evaluate as deal with prejudices and paradigms, finally, in our ability to build bridges and spaces needed to learn from the other, understanding that the concept of difference is beyond the reach of an absolute reason.

In our books (Stobäus \& Mosquera, 2012, 2013), about the theme of Full inclusion, we give some suggestions about how, for example deaf, blind, syndromics (such as Down or Asperger Syndrome) and other fields related to educational processes, that must be known and understood by teachers.

\section{Conclusion}

Teachers' education must be also considered as a "hermeneutic relationship", just as a way of productive relationships, better if it is in the interpersonal relationships (preparation in the teacher-student, observing student-student, or also student-parents-society). Here is just one of these arguments, knowing about the founding theories, one of the Gadamer's ideas we deepen in the article. We must also remember and reflect about other topics who influence, such as knowledge and skills of teachers who work in Special/Inclusive Education, including the concepts they use and how they see that it operates, as well as affectivity and healthier inter-personal relationships.

\section{References}

Adams, A., \& Junges, F. C. (2010). Historicidade e verdade nas ciências do espírito segundo Gadamer. [Historicity and Truth in the Sciences of Spirit According to Gadamer.] Protestantismo em Revista, 22, maio-ago.

Arendt, H. (2008). A condição humana (10th ed.). [The human condition.] Rio de Janeiro: Forense Universitária.

Dohms, K. P., da Lettnin, C., da C., Mendes, A. R., Mosquera, J. J. M., \& Stobäus, C. D. (2014). Affectivity of University Teachers: Personal, Social and Institutional Aspects. Psychology, 5, 1783-1793. http://dx.doi.org/10.4236/psych.2014.515185

Gadamer, H.-G. (2002). Verdade e método II. Complementos e Índice (2nd ed.). [Truth and Method II. Complements and Index.] Petrópolis: Vozes. 
Gadamer, H.-G. (2007). Verdade e método I: traços fundamentais de uma hermenêutica filosófica (8th ed.). [Truth and Method I: Basic Features of a Philosophical Hermeneutics.] Petrópolis: Vozes.

Hermann, N. (2002). Hermenêutica e Educação. [Hermeneutics and Education.] Rio de Janeiro: DPA.

Hermann, N. (2007). Phronesis: A especificidade da compreensão moral. [Phronesis: The Specificity of Moral Understanding.] Educação, 62, 365-376.

Lettnin, C., Dohms, K., Mendes, A. R., Stobaus, C. D., Mosquera, J. J. M., \& Jesus, S. N. de (2015). Evaluating Self-Esteem Levels of Brazilian and Portuguese Adolescents. Psychology, 6, 314-322. http://dx.doi.org/10.4236/psych.2015.64032

Marques, M. O. (2003). Formação do profissional da educação (4th ed.). [Education Professional Training.] Ijuí: Ed. UNIJUÍ.

Moita, M. C. (2002). Percursos de formação e de trans-formação. [Training and Processing Paths.] In: A. Nóvoa (Ed), Vidas de professors (pp. 111-140). [Teachers Lives.] Porto: Porto Editora.

Mosquera, J. J. M., \& Stobäus, C. D. (1984). Educação para a Saúde (2nd ed.). [Health Education.] Porto Alegre: D. C. Luzzatto.

Mosquera, J. J. M., Stobäus, C. D., \& Huertas, J. A. (2015). Teachers in Post-Modern Era: Narratives of Teaching Subjectivity. Creative Education, 6, 945-952. http://dx.doi.org/10.4236/ce.2015.610096

Nóvoa, A. (1995). Os professores e sua formação (2nd ed.). [Teachers and Their Training.]. Lisboa: Instituto de Inovação Educacional, Publicações Dom Quixote.

Rorty, R. (1990). El giro linguístico. [The linguistic turn.]. Barcelona: Ediciones Paidós Ibérica.

Rozek, M. (2010). Subjetividade, Formação e Educação Especial: histórias de vida de professoras. [Subjectivity, Education and Special Education: Teachers Life Stories.] Tese (Doutorado em Educação), Porto Alegre: Faculdade de Educação, Universidade Federal do Rio Grande do Sul.

Rozek, M. (2012). A formação de professores na perspectiva da Educação Inclusiva. In. C. D. Stobäus, \& J. J. M. Mosquera (Eds.), Educação Especial: em direção à educação inclusiva (4th ed., pp. 129-139). [Special Education: In Direction of the Full/Inclusive Education.] Porto Alegre: EdiPUCRS.

Rozek, M. (2013). As contribuições da hermenêutica de Gadamer para a formação de professores. [The Contributions of the Hermeneutics Gadamer for Teacher Education.] Educação, 36, 115-120.

Stobäus, C. D., \& Mosquera, J. J. M. (2012). Educação Especial: Em direção à educação inclusiva (4th ed.). [Special Education: In Direction of the Full/Inclusive Education.] Porto Alegre: EdiPUCRS.

Stobäus, C. D., \& Mosquera, J. J. M. (2013). Educação e Inclusão: perspectivas desafiadoras. [Education and Full Inclusion: Challenging Perspectives.] Porto Alegre: EdiPUCRS.

http://www.travessa.com.br/eBook_EDUCACAO_E_INCLUSAO_PERSPECTIVAS_DESAFIADORAS/eBook/12b8231 e-4bd9-422a-88c8-56a9f5f93752

Teixeira, T. C., Mosquera, J. J. M., \& Stobäus, C. D. (2015). Teachers Tell Us about Full Inclusion. Creative Education, 6, 1044-1052. http://dx.doi.org/10.4236/ce.2015.610103

Veiga, I. P. A. (2006). Docência: formação, identidade profissional e inovações didáticas. [Teaching: Training, Professional Identity and Teaching Innovations.] In: S. Maria et al. (Orgs.), Encontro Nacional de Didática e Prática de Ensino (pp. 467-482). [National Meeting of Teaching and Teaching Practice.] Recife: ENDIPE. 


\section{Submit or recommend next manuscript to SCIRP and we will provide best service for you:}

Accepting pre-submission inquiries through Email, Facebook, LinkedIn, Twitter, etc.

A wide selection of journals (inclusive of 9 subjects, more than 200 journals)

Providing 24-hour high-quality service

User-friendly online submission system

Fair and swift peer-review system

Efficient typesetting and proofreading procedure

Display of the result of downloads and visits, as well as the number of cited articles

Maximum dissemination of your research work

Submit your manuscript at: http://papersubmission.scirp.org/ 